\title{
POSSIBLE MODELS FOR THE REGULATION OF SIMULTANEOUS FUNCTIONING OF TRUTH AND RECONCILIATION COMMISSIONS AND CRIMINAL COURTS
}

\author{
Eszter Kirs*
}

In different types of political transition several measures are necessary to be taken in order to achieve an efficient transitional period. Actors of the conflict, former victims and perpetrators should be reconciled with each other so that further conflicts do not occur. Criminal accountability of those persons who bear the greatest responsibility for human rights abuses committed during the conflict period is inevitable, as well as the drawing of an overall picture of past events and the official acknowledgement of sufferings of the victims. Beyond these measures reparation needs to be provided to victims and usually fundamental changes in institutional structure need to be put in place as well, in order to ensure that viable changes, peace and security are installed in the affected society.

Numerous authors and human rights advocates argue that the accomplishment of criminal trials is not only an option but also a moral and legal obligation of the state and (where its support is necessary) of the international community in order to avoid the impunity of persons committing serious violations of human rights and humanitarian law. ${ }^{1}$ It is their duty according to the general and fundamental concepts of justice however, this approach simply does not work when the political circumstances do not make it possible for them to accomplish this obligation. These are situations where e.g. the internal criminal justice system has been broken down by the conflict or where the functioning of international criminal judicial bodies can be only rather symbolic as they are not able to run all the trials that should be processed in cases of thousands of perpetrators. In such cases criminal accountability does not gratify the interests of the affected society, which may be bound rather to prompt reintegration of former perpetrators into their local communities to the creation of a reliable picture of past events and a common experience of reconciliation.

In most of the recent post-conflictive situations criminal courts in themselves have not been sufficient to constitute justice in a general sense. The above mentioned objectives can be better served by an alternative form of transitional justice that can be realized through the establishment of truth commissions. In order to make a long-term consolidation achievable, in most cases there is an urgent need for both institutions. The present study is dedicated to the issue of how the relationship between truth commissions and criminal courts has been regulated in different post-conflictive societies of the last decades.

Following the introduction of the institution of truth and reconciliation commission in the South African example, specific situations will be discussed to indicate potential weaknesses of the regulation of the relationship between the two institutions of transitional justice.

In the case of Rwanda there was a unique attempt to modify a traditional conciliatory system in order to enable it to proceed in criminal matters. The institutional basis of the plan was the gacaca system which originally served the aim of reestablishment of the integrity of the local community in cases of marital, heritage or property disputes. With the modification these meetings were authorized to accomplish also a criminal judicial function. However, the broad involvement of non-professionals led to a controversial system violating basic fair trial

\footnotetext{
* Assistant lecturer, Department of International Law, Faculty of Law, Miskolc University 1 Jeremy Sarkin and Erin Daly, Too many questions, too few answers: reconciliation in transitional societies, in 35 COLUMBIA HUMAN RIGHTS LAW REVIEW 661, 712 (2003-2004)
} 
requirements. Furthermore, the irregular system of gacaca courts, as a category somewhere between criminal judicial bodies and truth and reconciliation commissions, seems not to meet the initial expectations regarding a fast decrease in the number of detainees sitting in the overcrowded prisons.

In the case of Sierra Leone a special issue appeared with the parallel functioning of the truth commission and the Special Court. The personal jurisdiction of the two institutions was determined in a properly separated way, and the reconciliation process provided an optimal solution for the reintegration of thousands of child soldiers. However, the lack of proper regulation restricted their efficiency to a large extent. One of its consequences was the low number of ex-combatants who appeared before the Truth and Reconciliation Commission.

Closer cooperation was established between the East Timorese Commission for Reception, Truth and Reconciliation and the Serious Crimes Unit. The Commission became an integrated part of the criminal judicial system that strengthened the quasi-judicial character of the institution. The greatest problem in this case was not a legal one but an issue of a political character. The success of the reconciliation process was undermined by a political decision, namely, the establishment of the Commission for Truth and Friendship that ensured impunity to perpetrators of the most serious crimes.

Finally, the last section of the study addresses the unavoidable issue of the relation between the International Criminal Court and future truth and reconciliation commissions. The dilemma of whether the ICC should hold back in certain situations in favor of a truth commission draws the attention to the fact that in some cases the notion of 'interest of justice' means more than pure criminal justice. The meaning of this notion needs to be determined according to the real interests of the people who were personally affected by the atrocities. In many countries emerging from an armed conflict or a repressive regime there is an urgent need for both retributive and restorative justice, therefore, in numerous cases the parallel functioning of criminal courts and truth and reconciliation commissions might be the best solution.

\section{SECTION 1. INTRODUCTION TO THE FUNCTIONING OF TRUTH COMMISSIONS: SOUTH} AFRICA

The functioning of truth commissions can be determined by four characteristics. First, they investigate the past; second, they examine not only a singular event but create an overall picture about abuses committed in a definite period of time; third, some sort of authority is ensured to these truth commissions that makes it possible for them to have greater access to information and greater security to undertake sensitive investigations; and finally, their functioning is limited to a definite period of time that is closed with the submission of a final report on their findings that is usually made public. ${ }^{2}$ The Latin American commissions were the first examples of this institution, although their mandate was determined in a narrower way than that of their descendants. Following the functioning of the Bolivian commission from 1982 to 1984 - which cannot be called successful as it did not even publish any final report - the first truth commission that received broader international attention was the Sábato Commission of Argentina that published its findings on atrocities that had occurred between 1976 and 1983 in a book called Nunca más (Never Again). The next decade brought the birth

2 Priscilla B. Hayner, Past Truths, Present Dangers: The Role of Official Truth Seeking in Conflict Resolution and Prevention, in INTERNATIONAL CONFLICT RESOLUTION AFTER THE COLD WAR, 338, 341 (National Academy Press, 2000) 
of two further commissions in the Latin-American region. The National Commission for Truth and Reconciliation was established in Chile in 1990, and investigated abuses resulting in death or disappearance over the previous seventeen years of the military regime. In the following year, 1991, a new phenomenon appeared in the region, namely, the intervention of the international community in the establishment of truth commissions. The Commission on the Truth for El Salvador was created not by domestic legislative tools but by the United Nations and due to neutrality concerns it became a pure international institution without any local personnel. The main task of this commission was to investigate past abuses that had occurred since $1980 .{ }^{3}$ The advantage of the determination of a narrower mandate for investigation was that the commission has been able to proceed in many more cases than in the case of Chile where the Commission investigated 2920 cases. $^{4}$ On the other hand, it has bound all the energy and capacity of the institution and therefore it has not been able to draw a reliable overall picture about the past that ought to be a crucial point of reconciliation.

Compared to the Latin-American commissions, the mandate of the South African Truth and Reconciliation Commission was much broader. It had the main task of gathering statements of former victims and perpetrators of the atrocities committed during the apartheid system, and in addition, it was responsible for deciding about amnesty and preparing proposals for necessary measures to be taken in the future in order to achieve long-term consolidation.

At the end of the apartheid system, which was an official policy in South Africa from 1948 to 1992, the first democratic elections were held in 1994. The African National Congress led by Nelson Mandela won the elections with 61 percent of the votes, and established the new government. They prepared the draft of the National Unity and Reconciliation Act, which was adopted in 1995.

Control over the enforcement of the Act became the task of the Truth and Reconciliation Commission created by the Act. The Commission had three organizational units: the Committee on Amnesty dealt with the amnesty pleas. It granted amnesty if the applicant revealed all the relevant facts and circumstances of the crime to which the application related and this human rights violation had been associated with a political objective. ${ }^{5}$ This conditional amnesty encouraged former perpetrators to participate in the reconciliation process. The second organizational unit, the Committee on Human Rights Violations existed as a forum, where the hearings of victims were held, and the Committee on Reparation and Rehabilitation dealt with proposals for damages to be paid for the victims. The functioning of the three Committees was controlled by 17 Commissioners. Desmond Tutu, the highly respected Anglican Archbishop of Cape Town was appointed to the position of the President of the Commission.

Compared to other truth commissions (Argentina, Chile, El Salvador, Sierra Leone, East Timor, etc.) the South African forum had an outstanding role as it can be called the most efficient one. Approximately 38 thousand cases were elaborated, and the testimony of 21 thousand victims and 7 thousand perpetrators was recorded. ${ }^{6}$ Use of the testifier's own language was ensured, safe hearings were possible and the hearings became public to a properly wide extent. The procedure of fact-finding went on with suitable intensity and efficiency compared to the other commissions.

\footnotetext{
3 Priscilla B. Hayner, Fifteen Truth Commissions-1974 to 1994: A Comparative Study, in 16 HUMAN RIGHTS QUARTERLY 597, 614-629 (1994)

$4 \quad I d, 645$

John Dugard, Is the Truth and Reconciliation Process Compatible with International Law? An Unanswered Question, in 13 SOUTH AFRICAN JOURNAL ON HUMAN RIGHTS 258, 259 (1997)

$6 \quad$ Anthea Jeffery, The Truth about the Truth Commission, AMERICAN BAR AssOCIATION, available at: http://www.abanet.org/irr/hr/spring00humanrights/jeffery.html
} 
There were several relevant factors that played a significant role in the functioning of this institution and this statement is applicable to all truth and reconciliation commissions. The composition of the commission plays a central role. Effort must be made to let as many diverse interest groups as possible participate in its work. On the other hand, this can increase the number of personnel, which will increase the expenses as well.

In territories where local individuals cannot be trusted to gain respect from all sides involved in the conflict or would be put in serious personal danger, foreigners must be preferred for appointment to the position of commissioner. The obvious disadvantage of this step will be that these commissioners probably will not be totally aware of the details and background of the specific situation.

The role of former participants in the conflict must be taken into consideration as well. The more former victims are involved into the work of the commission, the more credibly it can work in the protection of interest of victims. Moreover, if more former perpetrators, who kept their political positions, assume the role of commissioner, the enforcement of specific decisions will be more likely. ${ }^{7}$

For the suitable efficiency of the Commission's functioning it is necessary to ensure that the hearings lead to the collection of reliable, credible and detailed testimonies. The process of hearings is determined by numerous factors. One significant point is how widely public hearings occur, as they can serve as immediate education. From this point of view the retention of former perpetrators in power creates a fundamental obstacle. The circumstances of the hearing are also a determining factor, especially considering the special nature of these cases. Irregular procedure if often needed, such as visiting the victims in their own homes. The less formal the conversation is, the more possible it is to show empathy for the suffering and pain of victims, and in this way to increase the probability of gathering credible testimonies.

It is of outstanding importance to ensure that participants can talk in their own language, if necessary with the assistance of translators. Partially, it is a basic condition of revealing the facts in an appropriately detailed way. In addition, it can serve as a sign of respect and acceptance of the cultural and ethnic identity of the witness. This is especially necessary in a territory like South Africa with high ethnic diversity and eleven official languages. The conflictive situation also demands that the safety of witnesses be ensured. Appropriate testimony can be expected only if the witness does not need to worry about negative consequences on his own life or health and that of his family. ${ }^{8}$

All of these factors are fundamentally determined by the political situation. The period of violence might be finished in different ways. If the change occurred through a unilateral military victory, repression enforced by the new governing power will be determining. On the other hand, if consolidation was approached by negotiations, further discussions and factfinding will more probably appear based on voluntary participation. If the former perpetrators keep their political leadership positions to some extent, they might be able to undermine the efficiency of the fact-finding work with political pressure. Beyond that, the declaration of total amnesty will be much more probable in this case.

A highly dominant factor concerning the work of a commission is how widely its existence and its specific decisions are accepted by political parties, the political and military elite and the public. The support of public opinion can be based on ideological considerations. In the case of South Africa it could have been ensured by the Ubuntu theology which gives a central role to the principle of humanity and the Christian values of mercy and reconciliation,

\footnotetext{
7 Composition of Commission, in Strategic Choices in the Design of Truth Commissions, May 30, 2002 , available at: www.truthcommission.org/commission.php?lang=en\&cid=3\&case. $x=42 \&$ case $. y=7$

8 Proceedings, in Strategic Choices in the Design of Truth Commissions, May 30, 2002, available at: www.truthcommission.org/commission.php?lang=en\&cid=3\&case. $x=42 \&$ case $. y=7$
} 
if the still existing conflictive situation had not had destroyed the strength of this ideological background. Finally, the proposals of the Commission regarding financial reparations were not realized. Nevertheless, the truth-revealing work of the South African Truth and Reconciliation Commission was accomplished in such a highly successful way that this commission still can be considered the most efficient one so far.

Truth telling is a central element of most traditional African justice systems which have the main aim of reintegrating both perpetrators and victims in the society, in their local community. ${ }^{9}$ In this region the restoration of balance in the community is much more important than the punishment of the guilty as the traditional unit of the African society is the group and not the individual. ${ }^{10}$ In these cases the main goal of reconciliation can be better served by alternative forms of justice which do not concentrate on the faceless state which was "attacked" by the violation of law, but rather on individuals and communities who were directly affected by the crime. At the same time, these processes focus on the general desire of the whole population for peace and stability, "sacrificing" the possible personal interest of the victim for the accountability of the perpetrator. At the same time, personal interest cannot be underplayed, especially following extreme situations regarding high number of perpetrators and victims as occurred after the Rwandan genocide.

\section{SECTION 2. THE FAILURE TO GRANT CRIMINAL JUDICIAL AUTHORITY TO ALTERNATIVE INSTITUTIONS OF JUSTICE: RWANDA}

During the Rwandan genocide approximately 800 thousand people lost their lives during the spring of 1994. The broad involvement of the population in the killings created a situation that required a unique approach of the issue of how to call to account more than 650,000 perpetrators, as the number was initially estimated. Traditional models of criminal justice simply did not fit this situation. The extremely high number of people involved in the genocide was only one of the reasons to show that a new solution needed to be found. The other side of the problem was that the judicial system (which had not functioned properly even before 1994) had broken down and could not be reestablished from one day to the next. Most of the court buildings were destroyed or damaged and most of the professional lawyers (who had composed a narrow circle even before the genocide) were either dead, had fled the country, or were involved in the killings. As a consequence, only five judges and approximately fifty practicing lawyers remained in the country and were available for the reestablishment of the Rwandan judicial system. ${ }^{11}$

The International Criminal Tribunal for Rwanda, established by the United Nations in 1994, could not be considered as a possible judicial body to solve this problem, especially because its mandate was to proceed in cases of high-level perpetrators. In this sense, however, it facilitated the "cleansing process" of the political arena, completing 27 cases of leaders and organizers of the genocide. It imposed life-imprisonment on, among others, Jean Kambanda, the former Prime Minister of the interim government of 1994, Jean de Dieu Kamahunda, the former Minister of Higher Education and Scientific Research, and Emmanuel Ndindabahizi, the former Minister of Finance, and condemned to long-term imprisonment numerous

\footnotetext{
9 Charles Villa-Vicencio, Why perpetrators should not always be prosecuted: where the International Criminal Court and Truth Commission meet, in 49 EMORY LAW JOURNAL 205, 211 (2000)

$10 \quad$ SARKIN and DALY (note 1), 671

11 Erin Daly, Between Punitive and Reconstructive Justice: the Gacaca Courts in Rwanda, in 34 NEW YORK JOURNAL OF INTERNATIONAL LAW AND POLITICS 355, 368 (2001-2002)
} 
Interahamwe leaders, mayors and préfets who had been the highest-level government officials in the administration-units of Prefectures and were most responsible for the massacres in the country. ${ }^{12}$

Nevertheless, it must be mentioned that the ICTR has not run any trial in cases of RPF ${ }^{13}$ leaders who were responsible for serious atrocities, which might raise some doubts regarding the impartiality of the Court and therefore may undermine its reputation. Moreover, there are still dominant figures whose cases should be proceeded by the Court but who are fugitives from justice, such as Félicien Kabuga, who was one of the masterminds of the genocide, financed the importation of machetes and other weapons used for the massacres and owned the Radio Television Libre Mille Collines. ${ }^{14}$ As long as these suspects are walking free, it cannot be stated that the ICTR has accomplished its mission and it is also not probable that it can close its functioning before 2008, as was the original plan. The Rwandan domestic judicial system is still not ready to deal with such high-profile cases, and this situation was far worse in the years directly following the genocide. However, it was obvious that in the case of lower-level perpetrators a solution had to be found inside the boundaries of the state.

The declaration of any kind of amnesty was not an alternative, as this idea faced radical objections from the population. Even the possibility of a South African style reconciliation process was strongly opposed by the victims, who demanded the enforcement of full criminal accountability. Without this first inevitable step reconciliation would have remained an empty word without realization. On the other hand, the enforcement of accountability did not seem to be an easy deal, especially as the new government was not open to any kind of external support, refusing to accept foreign lawyers, who could have strengthened the domestic judicial system. ${ }^{15}$

The first attempt at a solution was the involvement of confession as a mitigating factor in the regular criminal proceedings. In this way confession could contribute to the reduction of the high number of detainees in the overcrowded Rwandan prisons. Nevertheless, there were serious concerns about the procedures as they did not guarantee due process. Prisoners who confessed their crimes could not be separated from those who did not make the same decision, raising further security problems. Moreover, statements given by those who had confessed (mostly perpetrators who were already in prisons waiting for their sentence or for their trials to be commenced) were not properly analyzed, that would have been necessary for truth-telling, as this task was not included in the mandate of the courts.

\section{Paragraph 1. The irregular solution of gacaca courts}

The special situation required an extraordinary solution, and the establishment of an alternative system of transitional justice seemed to be unavoidable. Eventually the modification of the traditional gacaca system became this alternative solution. The traditional process served the aim of settlement of internal disputes of local communities and reestablishment of their integrity. These were ad hoc meetings of the inhabitants of a village

\footnotetext{
12 Status of Cases (WEBSITE OF THE INTERNATIONAL CRIMINAL TRIBUNAL FOR RWANDA), November 10, 2007, available at: www.69.94.11.53/default.htm

13 The Rwandan Patriotic Front (RPF) was a rebel group founded in 1987 composed primarily of Tutsi refugees seeking the right to return to Rwanda. Its forces put an end to the genocide in 1994. RPF is currently a dominant political party of Rwanda.

14 Trial Watch, November 9, 2007, available at: www.trial-ch.org/en/trialwatch/profile/db/facts/felicien_kabuga $96 . \mathrm{html}$

William A. Schabas, Genocide Trials and Gacaca Courts, in 3 JouRnAL OF INTERNATIONAL CRIMINAL JUSTICE 879, 883 (2005)
} 
chaired by the leaders of the community. The main aim of these sessions was the settlement of marital, property or heritage disputes and they did not deal with criminal cases or result in individual judgments. It rather led to community solutions and many times required only a symbolic act of reparation from the perpetrator, such as providing beer to the members of the community as a gesture of reconciliation. ${ }^{16}$

This system was the basis of the solution that turned into the creation of a decentralized, non-reliable and unfair criminal justice system. The first Organic Law no. 40/2000 on the establishment of gacaca courts included a plan for an ideal structure for the gacaca system which seemed to be utopian under the actual circumstances. According to the original plan 250,000 individuals would have been employed as lay judges. After the first years it became obvious that this strategy could not be followed in reality, therefore the new Organic Law no. $16 / 2004$ was adopted in order to simplify the system, with a reduction of personnel to $170,000 .{ }^{17}$ This new law became the basis for the functioning of the gacaca courts, which began operation in 2005 .

There are two main levels in the gacaca system: at the cell level more than 9,000 courts were established as pre-trial chambers and at the sector level more than 1,500 "higher level" courts deal with more serious cases, while the Sector Courts for Appeal proceed in cases of appeal. In the pre-trial process the cell level courts prepare lists of names of those who lived in the affected community before the genocide, those who were killed and the people entitled to receive compensation and those who can be accused of the involvement in the genocide. Indeed, they are supposed to prepare a history of the local community during the genocide. ${ }^{18}$ Their other main task is to categorise the crimes and put the accused individuals in the right category. This classification system determines which courts have authority to proceed in the case of a certain perpetrator. The first category of crimes falls outside the authority of gacaca courts. It includes leading, planning or organizing the genocide, killing of more than one person, rape, and, following the 2004 Organic Law, torture, degrading treatment of a human corpse and the commission of more acts of sexual abuse. Killing of one person belongs to category 2 , causing physical injury appears in category 3 , and crimes committed against property count as category 4 crimes. Cases belonging to categories 2 to 4 can be proceeded by the gacaca courts, while category 1 perpetrators shall be called to account by regular criminal courts. ${ }^{19}$

Similarly to criminal proceedings, confession became an important mitigating factor in the gacaca proceedings. Those who confessed before their name appeared on the list of the accused persons can be sentenced to 1-3 year imprisonment in the case of category 3 crimes, and to 7-12 years in the case of category 2 crimes. In case of a confession after accusation, it may mean an imprisonment of 3-5 years in category 3 and a sentence of 12-15 years imprisonment in category 2, while without confession imprisonment would be 5-7 years and 25 years or more, respectively. For category 4 crimes, perpetrators may be obliged to pay compensation to the family that was affected by their criminal act. ${ }^{20}$

\section{Paragraph 2. Consequences of the involvement of too many lay judges in criminal justice}

16 Lars Waldorf, Rwanda's failing experiment in restorative justice, in HANDBOOK OF RESTORATIVE JUSTICE 422, 425 (Routledge, 2006)

SCHABAS (note 15), 894

WALDORF (note 16), 426

DALY (note 11), 371-373

Charles Villa-Vicencio, Rwanda: Balancing the Weight of History, in THROUGH FIRE WITH WATER: THE

RoOts of DIVISION AND THE POTENTIAL FOR RECONCILIATION IN AFRICA 1, 22 (Africa World Press, 2003) 
This system could have met the desire of victims for criminal accountability and at the same time contributed to the reduction of number of detainees living in overcrowded prisons but reality brought obstacles which had not been expected at the beginning. The first problem appeared with the increase of further accused perpetrators identified by their fellows. The more former perpetrators confessed in the hope of a restricted sentence, the more new names appeared on the list of accused individuals, which resulted in an unexpected increase in the number of detainees. If we consider the cell, sector and appeal levels together, between 10 March 2005 and 14 July 2006 2,365 perpetrators were released, as they were found not guilty or were sentenced to a prison sentence less than or equal to the time already spent in detention. Meanwhile, 2,579 accused persons were condemned to imprisonment longer than the time spent in prison, imprisonment of 25-30 years was imposed on 1,404 perpetrators and at the appeal level only 93 sentences were alleviated. ${ }^{21}$ These statistics show that this alternative justice system established with the aim, among others, to reduce the number of detainees in overcrowded prisons has not yet met this expectation.

The results of the trials up to now do not indicate a high efficiency of the process if we consider the original plans for the closure of the gacaca process in December 2007. Out of the 818,564 persons who have been prosecuted for having committed genocide, 741,295 were qualified as perpetrators of crimes falling into category 2 and 3 and as such fall under the authority of gacaca courts. ${ }^{22}$ In the 15 - month period ending in the summer of 2006 , only 8,836 trials were completed. On the sector level 7,721 trials were completed, i.e. 22 percent of the files was forwarded to sector courts. Appeal courts tried 1,115 further perpetrators that covered 67 percent of the total number of cases sent to the appeal level. ${ }^{23}$ These numbers indicate that the functioning of sector level courts has not been as fast as was expected, and even with radical change, it could not be likely to achieve the original goal of closure of the proceedings before gacaca courts till the end of 2007.

The other problem was that the whole system was built mostly on non-professionals without any salary, which opens a door to corruption. In many cases they are personally affected by the atrocities. As an extreme example can be mentioned the case of FrancoisXavier Byuma, a member of the local non-governmental organization, Turengere Abana (Rwandan Association for the Protection and Promotion of the Child) who, as a member of this organization, investigated the case of a person who was alleged to have raped a 17-yearold girl. Although the Organic Law no. 10/2007 ordered the dismissal of judges from the gacaca courts if they commit any act which is incompatible with the quality of a person of integrity, Mr. Byuma was sentenced to 19 years' imprisonment, which decision was taken by the very same person who was the subject of his investigation, but recently works as a gacaca judge.

This extreme example illustrates well the fact that gacaca judges make decisions about long-term (and even life) imprisonment in proceedings where fair trial guarantees cannot be ensured. Gacaca courts are entitled to issue arrest warrants and subpoenas and to proceed with search and seizure, but the accused persons do not possess the right to see their own files before their hearings and they are not provided legal representation either. The accused do not have the right to silence, since they are obliged to answer all the questions posed by the court. Statements given by witnesses are often not reliable, since either the witness had been

21 Report on Trials in Pilot Gacaca Courts, NATIONAL SERVICE OF GACACA JURISDICTIONS, November 5, 2007, available at: $\underline{\text { www.inkiko-gacaca.gov.rw/En/EnIntroduction.htm }}$

22 Summary of Person Prosecuted for having committed Genocide, NATIONAL SERVICE OF GACACA JURISDICTIONS, November 5, 2007, available at: www.inkiko-gacaca.gov.rw/En/EnIntroduction.htm

23 REPORT ON TRIALS IN PILOT GACACA COURTS (note 21) 
corrupted or had a personal interest in not telling the truth (as a perpetrator for mitigation, or as a victim out of vengeance). At the same time both witnesses and judges are targets of street attacks. $^{24}$

Beyond mentioning the numerous weak points of the system, it must be admitted that gacaca courts ensure a forum for perpetrators, victims and affected members of the community to meet and discuss together all the past events, that can become a common experience of truth revealing and in this way may facilitate reconciliation and reintegration of former perpetrators into their communities. ${ }^{25}$ Furthermore, its processes require less time than regular criminal proceedings and education was not a problem to solve at the establishment of the system as it is based on non-professional personnel. On the other hand, many Rwandans do not trust these courts and boycotted them with their disappearance or have fled to neighboring countries fearing false accusations and unfair trials. ${ }^{26}$ The question still plays a paramount role: how can long-term reconciliation be reached through a vengeful system where judges are the victims of the perpetrators?

\section{SECTION 3. THEORETICAL APPROACH TO THE ISSUE OF REGULATION}

\section{Paragraph 1. Advantages of criminal jurisdiction related to reconciliation}

Following the examination of the alternative solutions of transitional justice in South Africa and Rwanda, the name of another country appears from the African continent in the context of truth and reconciliation commissions. This country is Sierra Leone, in the case of which the issue of the relationship between the commission and criminal courts played a central role.

The possible role of accountability in a transitional period depends on the specific circumstances characterizing the situation. There are no recipes telling how to "cook" an optimal transition and the "the dessert" of reconciliation. However, there are general conclusions and assumptions that can be drawn based on past experience. Justice Goldstone emphasized five positive contributions of criminal proceedings that can ensure reconciliation: individualization of guilt, public and official acknowledgement to the victims, an accurate recording of history, efficient deterrence, and finally, revealing the role of state institutions in the conflict and human rights violations. ${ }^{27}$ In case of international criminal tribunals the attention of the international community is an additional factor.

The leaders who were earlier the representatives of a country or community and who committed serious human rights violations (ideally) become criminals in a trial. In this way, Nuremberg transferred the responsibility for war crimes from the whole group of German people to individuals who could really be held responsible for atrocities committed during the World War II. ${ }^{28}$ The same individualizing effect can be achieved on the level of the members

\footnotetext{
$24 \quad$ Jacques Fierens, Gacaca Courts: between Fantasy and Reality, in 3 JOURNAL OF INTERNATIONAL CRIMINAL JUSTICE 896, 911 (2005)

${ }_{25} \quad$ DALY (note 11), 376

26 Erin Daly and Jeremy Sarkin, RECONCILIATION IN DividED SOCIETIES, 84 (University of Pennsylvania Press, 2007)

$27 \quad$ Richard Goldstone, Justice as a tool for peace-making: truth commissions and international criminal tribunals, 28 NEW YORK UNIVERSITY JOURNAL OF INTERNATIONAL LAW AND POLITICS 485, 488-490 (19951996)

$28 \quad I d, 489$
} 
of the community by domestic criminal trials. In other words, one cannot suppose anymore that the neighbor of someone is also a criminal just because they live next to each other, if the justice system does not confirm it. Obviously, the pure advantage of individualization can be achieved only if the judicial system works in a proper way, and in a post-conflictive society this is far from being evident.

Concerning the acknowledgment of past abuses it must be emphasized that victims do not need only an empty gesture of apology, but an official acknowledgement of all the terrifying events that resulted in memories that haunt them from night to night. After the publication of the Final Report of the South African Truth and Reconciliation Commission, President Mandela apologized publicly to victims on behalf of the government. ${ }^{29}$ This nice gesture was not enough for the real solution of problems. Lack of sufficiently broad political support for the strict accomplishment of criminal proceedings and reasonable financial reparation hindered smooth reconciliation. ${ }^{30}$

Criminal accountability of those who were not granted amnesty could be a sufficient official acknowledgement of past events. Furthermore, in cases of criminal proceedings the broad participation of victims can contribute even more to the healing of their wounds. Past international criminal tribunals did not concentrate enough on this issue, but the establishment of the International Criminal Court (hereafter: ICC) brought a change of approach also in this respect. The Rome Statute and the Rules of Procedure and Evidence ensure the opportunity for the victims to participate widely throughout the process. This can be illustrated also by the establishment of the Victims and Witnesses Unit. (However, this chance is ensured only to those who can be used as witnesses before the Court. It is hard to imagine though that for example an average Ugandan farmer would ever travel at his own expense to the Hague in order to listen to proceedings that could help him to understand the past. In this regard, the positive effect of the ICC processes on reconciliation is limited.) Those victims who appear before the Court benefit from the "recovery" measures, including expertise in post trauma rehabilitation and the measures taken for their protection. Moreover, the Trust Fund established for the benefit of victims and their families gives a kind of reparative mandate to the ICC. ${ }^{31}$

Revealing the truth after a change of regime or an armed conflict is a crucial point of the transition process. It is true that without a proper knowledge and education of history a healthy society is impossible to build, and all the dark spots of the past can undermine the future of a society. The words of Justice Goldstone cannot be debated: "public exposure of the truth is the only effective way of ensuring that history is recorded more accurately and more faithfully than otherwise would have been the case. The Nuremberg Trials have made the work of Holocaust deniers far more difficult." 32 Nevertheless, it is not obvious whether the immediate revelation of facts would facilitate reconciliation. ${ }^{33}$

The issue of contribution of criminal trials to truth-telling about the role of state institutions raises a further dilemma. When the role of state institutions is highlighted by a domestic court, the immediate question to be posed is who will examine the role of the judiciary in past abuses, since without its silence they could not have occurred. This part of the truth sometimes demands an independent institution to examine the role of judicial bodies.

29 South Africa: The South African Truth and Reconciliation Commission, in STRATEGIC CHOICES IN THE DESIGN OF TRUTH COMMISSIONS, May 30, 2002, available at:

www.truthcommission.org/commission.php?lang=en\&cid=3\&case. $x=42 \&$ case $. y=7$

See further details in the next chapter.

31 Jürg Lindenmann, Transitional justice and the International Criminal Court: some reflections on the role of the ICC in conflict transformation, in PROMOTING JUSTICE, HUMAN RIGHTS AND CONFLICT RESOLUTION THROUGH INTERNATIONAL LAW, 315, 328 (Martinus Nijhoff Publishers, 2007)

32 GOLDSTONE (note 27), 489

33 See further arguments in the next chapter. 
The investigations of an international criminal tribunal or the ICC prove that the international community pays attention to the development of the transitional situation. This is especially significant in countries where the judicial system has broken down and there is no way to call to account those who bear the greatest responsibility. In this way, the proceedings can contribute to the actual negotiations in a highly positive manner. The domestic actors of public life who work on the transition to democracy no longer must depend only on the poor facilities within the boundaries of their country, and they can have a stronger hand even in deciding which parties can sit at the negotiating table. ${ }^{34}$ Besides, those former political or military leaders who would hinder the positive outcome of the negotiation process can be "knocked out" both from the course of the transitional discourse and the future political arena. According to Jürg Lindenmann, in situations where there is a strong public opinion that the international community failed to intervene in order to prevent further abuses the involvement of the ICC is particularly important as proof for the fact that the international community "cares". ${ }^{35}$ I would reverse this statement, saying rather that international criminal jurisdiction cannot be a solution for providing assistance as a subsequent excuse for having failed to intervene at the right time.

\section{Paragraph 2. Possible disadvantages caused by criminal justice}

While there are arguments that criminal courts are the most efficient tool for the prevention and abolishment of collective guilt individualizing responsibility, others see criminal jurisdiction as vengeful, continuing a cycle of hatred. ${ }^{36}$ I share the opinion of those who state that the deterrent consequence of accountability can by all means be debated on the level of political or military leadership. It is far from sure that powerful political forces driven by ideological factors would ever be affected by the possibility of future prosecution. Furthermore, if perpetrators of grave crimes cannot be arrested, the possible "knock out" effect fails, and in this way it can even hinder the negotiation process, making the leaders of repressive regimes more reluctant to contribute to political consolidation. ${ }^{37}$ The same feature can be advantageous on the other side of the conflict, as it can encourage resistance forces to sit at the negotiation table, such as in the case of Uganda where leaders of the LRA became open for negotiation as a result of the proceedings initiated by President Museveni and his government at the ICC. (It is another problem that they soon demanded the suspension of the proceedings which were referred to from then on as obstacles in the peace process.) Uganda is one of the cases showing that recent transitions tend to develop rather through negotiation than the military victory of one side to the internal conflict. Accordingly, there is no place for "victor's justice". In many cases the former military or political forces remain in power, which may mean that too much pressure for criminal proceedings can lead to the risk of the revival of the conflict.

Further characteristics and consequences of criminal proceedings can be emphasized in relation to the role they really play in reconciliation. The prosecution examines the facts relevant to the case and charges, just as the defense tries to extract parts of the truth which are useful for arguments. Criminal courts are not in a position to analyze statements of victims in

\footnotetext{
$34 \quad I d, 19$

35 LINDENMANN (note 31), 327

$36 \quad$ Laura M. Olson, Provoking the dragon on the patio, Matters of transitional justice: penal repression vs. amnesties, 88 INTERNATIONAL REVIEW OF THE RED CROSS 275, 291 (2006)

$37 \quad$ VILLA-VICENCIO (note 9), 210
} 
such a high number that would be necessary to draw an overall picture of the past. This leads to a partial truth. On the other hand, if trials are carried out in a way to serve as history lessons as well, this can easily create show trials, therefore, the main function and aim of trials cannot be to reveal the truth on a large scale, but to examine the facts and events limited to the specific cases at hand. ${ }^{38}$ Nevertheless, there are suggestions that in the case of the ICC it could be useful for reconciliation if the Office of the Prosecutor - as an international, objective examiner of facts - would issue a summary report of its findings following the model of independent prosecutors in the United States who submit such conclusive reports after the closure of their work. ${ }^{39}$

Considering the situation of the whole society even the justice that trials ensure serves only in part the common interests of local people. Focusing on the desire of victims for accountability, trials do not affect the community of the perpetrator in a positive manner. As a result, reconciliation in the community of the victim is facilitated but not that in the community of the perpetrator.

The other face of individualization is that trials usually create an "us-versus-them" dynamic. A view may emerge that those criminals who sit before the court are guilty for all the terrifying events, although it is clear that politicians, for instance, could not have been put in the relevant decision-making positions without the contribution of average citizens. In South Africa, for example, the appointment of high-level representatives of the apartheid system, such as Magnus Malan (former minister of defense) or Eugene de Kock (former head of the secret assassination unit) would not have been possible without the votes of middle class suburban housewives and white businessmen in favor of the National Party. ${ }^{40}$

Considering the South African example, one must face another possibility that can occur and that can hinder the process of reconciliation: namely, the negative outcome of these high-profile proceedings. Magnus Malan and his 19 co-accused fellows were acquitted, although their activity to establish hit squads in order to kill political opponents was proven. In 2002, a number of other acquittals occurred in cases of politically motivated crimes. Wouter Basson, the head of the apartheid's chemical and biological weapons program, was acquitted by the Pretoria High Court on all charges of murdering anti-apartheid activists, although there were 150 witness statements as evidence against him. ${ }^{41}$ In the same year President Mbeki granted pardons to a number of other persons who were sitting in prison for politically motivated crimes. ${ }^{42}$ The official position is that these trials were based purely on their merits, but it is probable that political reasons were behind these unreasonable acquittals and pardons. According to this view, the main aim was to facilitate the governance of the country by putting an end to trials related to apartheid, and that it was not anymore about giving up justice for a more noble aim of transition to democracy, but about making it easier to manage the affairs of the state. At the time of change of regime in 1994 and 1995, civil society, which had originally opposed the idea of any kind of amnesty, could accept the conditional amnesty in order to achieve a higher aim of smooth transition, but in 2002 there were no morally acceptable reasons for granting a de facto general amnesty. The common opinion of the population is well mirrored by the reaction of a non-governmental organization, Jubilee South Africa, about the Malan case: "the trial revealed only that apartheid's powerful military and secret service bosses still have much to hide and still have

\footnotetext{
$38 \quad I d, 211-212$

39 Priscilla B. Hayner, UnsPeAKABle Truths-FACING THE CHALLENGE OF TRUTH COMMISSIONS, 212 (Routledge, 2002)

$40 \quad I d, 101$

$41 \quad$ Jeremy Sarkin, To prosecute or not to prosecute?, in THE PROVOCATIONS OF AMNESTY: MEMORY, JUSTICE AND IMPUNITY, 237, 249 (Africa World Press, 2003)

42 $\quad$ Id, 253-254
} 
the means to obstruct the wheels of justice." ${ }^{43}$ Whatever the real reasons are, these doubts prove the great significance of fair trials in the process of reconciliation.

Meanwhile, if we consider the issue of "lower level" perpetrators, we have to face the reality that in some post-conflictive situations there is no possibility of accomplishing criminal trials in all the relevant cases. The best example might be Rwanda, where around 650,000 Hutus were involved in the genocide who ought to have been called to account by a non-existing domestic criminal judicial system, not to mention the fact that most of these people were not only perpetrators but also victims used as tools of a well-organized system of genocide. As it was mentioned earlier, in the course of the conflict the country was destroyed, there were no working institutions to enforce law. Many court buildings were wrecked, the few qualified legal professionals were either killed, participated in the genocide or fled the country. ${ }^{44}$ In such situations an alternative form of justice has to be found in order to avoid a long-term catastrophe. In these cases strictly insisting on the legal obligation of criminal justice can result in further decline of the affected country and in order to avoid such decline, alternative forms of justice are turned to.

\section{Section 4. Parallel functioning OF THE TRUTh COMMisSion AND the SPECial COURT: SiERRA LEONE}

A major argument against truth commissions is that their functioning is incompatible with the notion of justice as their process rejects prosecution and therefore can be seen as a threat to the interest of justice. It is also true that not to call to account former perpetrators would undermine the newly born democracy. A blanket amnesty should be refused under any circumstances, which is already a generally accepted view of the international community. Accordingly, reconciliation processes cannot be used with the aim of disguising a general amnesty, as was the idea of Mario Enriquez, former minister of defense of Guatemala: "We are fully in support of a truth commission. Just like in Chile: truth, but no trials." ${ }^{45}$ Impunity would undermine also the realization of the aims of reconciliation as it could encourage the victims to take revenge and the perpetrators to go on with violent acts. Nevertheless, there are alternative solutions available beside trials which do not allow the denial of past events, but help the society to rather pay attention to the future than to the past.

It is very important to see that truth commissions are not second alternatives to criminal courts, but a better kind of institution to address reconciliation. These two forms of justice have different aims and different tools for achieving them, and in this way, they can work simultaneously as well, supporting each other's function. Truth and reconciliation commissions can play a significant educational role in the field of human rights, but a change of views of the abusive leadership is not likely to be produced by them. This is one of the reasons why parallel functioning of the two institutions might be the best solution for handling a post-conflictive situation.

At this point we cannot mention too many practical examples for this solution, as there have been only a few places where proceedings before the truth commission were connected to criminal trials, such as in Bolivia and Argentina, where criminal trials could be commenced

\footnotetext{
$43 \quad$ Id, 250

$44 \quad$ Erin Daly, Between Punitive and Reconstructive Justice: the Gacaca Courts in Rwanda, in 34 NEW YORK JOURNAL OF INTERNATIONAL LAW AND POLITICS 355, 364-366 (2001-2002)

$45 \quad$ Enriquez gave this statement in 1994 at a meeting with human rights advocates.

HAYNER (note 39), 86
} 
as a result of truth commission investigations. ${ }^{46}$ Special alternatives can also be considered, such as the example of Ethiopia where no truth commission was expected to accomplish investigations that eventually could have been used by the criminal courts, but rather the Special Prosecutor's Office was entrusted to publish a truth-commission-like report about the abuses committed during the Mengistu regime. However, finally the SPO dropped the plan of publishing the report as it decided to concentrate only on prosecutions. ${ }^{47}$ According to the "casting" in Sierra Leone, the Special Court deals with the perpetrators who were responsible for the most serious crimes committed during the armed conflict and the cases of lower level perpetrators fell under the authority of the Truth and Reconciliation Commission.

\section{Paragraph 1. Establishment of the two institutions}

During the eleven years of Sierra Leone's civil war both the government and peacekeeping forces and members of the rebel armed groups became responsible for the most serious international crimes. The long list of abuses committed against the civilian population included willful killing (many times with an extreme brutality such as by burning), mutilation, recruitment of children and sexual abuses. In this case, crimes committed against civilians did not appear as a collateral damage but as a method of warfare.

At the end of the hostilities the significant question was raised how to call to account the persons responsible for the most serious crimes of an international character, and how to ensure appropriate and efficient procedure in their cases since the UN did not recognize the general amnesty declared by the legislation of Sierra Leone related to international crimes. The jurisdiction of the International Criminal Court was excluded as it applies only to crimes committed after July 1, 2002 when the Rome Statute entered into force. A special solution was necessary, which was later declared in the agreement between the UN and the government of Sierra Leone on January 16, 2002. The objective was to establish a Special Court. The UN Assistance Mission for Sierra Leone (UNAMSIL) was given the task of ensuring the safety of the functioning and of the personnel of the court located in Freetown, the capital of the country, and the government was obliged to co-operate with the judicial body and support it in all parts of the procedures, such as in the identification or location, arrest and detainment of perpetrators, their transfer and the disclosure of necessary documents to the Court. ${ }^{48}$

As opposed to the creation of the already existing ad hoc tribunals of an international character (ICTY, ICTR), this judicial body was established with a mixed character, including national and international elements. The reason for this kind of establishment was the will of the government to preserve a possibility to influence the functioning of the Court. Meanwhile, the establishment of a new and expensive international tribunal would not have been supported by the international community. The obvious disadvantage was that since it was not established by the power of the Security Council pursuant to Chapter VII, it was not

\footnotetext{
$46 \quad$ HAYNER, (note 3) 604

47 Priscilla B. Hayner, Past Truths, Present Dangers: The Role of Official Truth Seeking in Conflict Resolution and Prevention, in INTERNATIONAL CONFLICT RESOLUTION AFTER THE COLD WAR, 338, 348 (National Academy Press, 2000)

48 Agreement between the United Nations and the Government of Sierra Leone on the Establishment of a Special Court for Sierra Leone. January 16, 2002, available at: www.specialcourt.org/documents/Agreement.htm
} Art. 16-17 
empowered to issue binding orders to states and therefore the will of states to co-operate played a more significant role. $^{49}$

Beyond the appointment of Court officials, the Court's international character is manifested in the fact that the functioning of the ICTY and ICTR was a sample to follow, especially in terms of the creation of the rules of procedure. ${ }^{50}$ Although the Security Council had asked the Secretary-General to consider the possibility of the Court sharing the judges of the Appeals Chamber with the two already existing ad hoc tribunals, the proposal was rejected. $^{51}$ Notwithstanding, decisions of the Appeals Chamber of the ICTY and ICTR became influential on the jurisdiction of the Appeals Chamber of the Special Court. ${ }^{52}$

The Statute of the Special Court ensured priority to the Court against the national criminal judicial bodies. Accordingly, the Court may issue an order at any time during the proceedings requiring the domestic criminal courts to give a certain case into its authority. ${ }^{53}$ Its relation to the Truth and Reconciliation Commission was more debatable.

Already the drafters of the Lomé Agreement were inspired by the high number of lower level perpetrators to mention the necessity of the establishment of a truth commission. In 1999 the UN High Commissioner for Human Rights, Mary Robinson offered her help to President Kabba for the establishment of the Commission. The President accepted the offer, which was followed by the two week visit of two officers from the UN Office of the High Commissioner for Human Rights (OHCHR) with the aim of analyzing the local situation and suggesting alternatives for the support of the Office. Finally, the government drafted a bill according to the suggestions of the Office, which became the basis for the act of February 22, 2000 on the establishment of the Truth and Reconciliation Commission. ${ }^{54}$

The Truth and Reconciliation Commission was established as a national institution by internal legislation but it had a strong international character. The Selection Coordinator for the appointment of the commissioners was the UN Special Representative of the SecretaryGeneral in Sierra Leone. The Chair of the Commission ${ }^{55}$ was appointed by the President of Sierra Leone, the Methodist bishop Joseph Humper, and the retired justice of the High Court of Sierra Leone, Laura Marcus-Jones became Deputy Chair, according to the recommendation of the Selection Coordinator and Mary Robinson. They also had a dominant role in the appointment of the further five members of the Commission. In addition to them the Selection Panel, composed of dominant institutions of Sierra Leone ${ }^{56}$, was working on the initial and further appointments. ${ }^{57}$

The project of the establishment of the Commission was a program of the OHCHR and its main financial sources were also ensured by international actors. As a result, some doubts arose as to the independence of the institution, as a significant part of the 4 million USD support (earlier planned for 10 million USD) arrived from the UN, the United States, the

\footnotetext{
49 Avril McDonald, Sierra Leone Special Court, in ENCYCLOPEDIA OF GENOCIDE AND CRIMES AGAINST HuMANITY, 955 (Macmillan Reference USA, 2005)

50 Statute of the Special Court. January 16, 2002, available at: www.sc-sl.org/scsl-statute.html Art. 14 (1)

$51 \quad$ MCDONALD (note 49), 956

$52 \quad$ Statute of the Special Court (note 50), Art. 20 (3)

53 Statute of the Special Court (note 50), Art. 8

$54 \quad$ Richard Bennett (UNAMSIL), The Evolution of the Sierra Leone Truth and Reconciliation

Commission, available at: www.sierra-leone.org/trcbook-richardbennett.html

55 The Truth and Reconciliation Act. February 22, 2000, available at: www.sierraleone.org/trcact2000.html Part I Art. 1

Members of the Selection Panel: the President of Sierra Leone, the RUF, the AFRC, the Inter-religious Council, the National Forum for Human Rights and the National Commission for Democracy and Human Rights.

57 The Truth and Reconciliation Act (note 55), Schedule: Procedure for the Selection of Nominees for Appointment to the Commission.
} 
United Kingdom, the European Union, Denmark, Sweden and Norway. The government of Sierra Leone could provide only 100,000 USD for this aim. ${ }^{58}$

At the beginning of the functioning of the Commission numerous non-governmental organizations were extremely enthusiastic and promised their support for the future. This enthusiasm diminished with the decrease of financial support and at the end, the International Center for Transitional Justice remained almost the only one giving real support through technical means and expertise. The other organizations failed to provide the promised assistance.

\section{Paragraph 2. Differences regarding personal jurisdiction}

Regarding the relation between the Special Court and the Truth and Reconciliation Commission it is worth beginning with the examination of their personal scope of authority that illustrates well the difference between the mandates of the two institutions. Following the closure of the debates on the personal jurisdiction of the Court, the draft suggested by the 1315 Security Council Resolution ${ }^{59}$ was included in the Statute, being preferred to the opinion of the UN Secretary-General. According to this provision:

"The Special Court shall [...] have the power to prosecute persons who bear the greatest responsibility for serious violations of international humanitarian law and Sierra Leonean law committed in the territory of Sierra Leone since 30 November 1996, including those leaders who, in committing such crimes, have threatened the establishment of and implementation of the peace process in Sierra Leone." 60

The objection of the Secretary-General affected the second part of the provision which emphasizes the role of leaders and their responsibility, arguing that the Security Council influenced the Prosecutor of the Court. He stated that this paragraph of the Statute would restrict the authority of the Court to crimes committed by political and military leaders. ${ }^{61}$ Despite his objection, the personal jurisdiction was finally restricted to these persons.

In the case of peacekeepers, the authorities of the sending state were given exclusive jurisdiction. ${ }^{62}$ This issue did not become a subject of debate. A much bigger dilemma was how to call to account juvenile and child perpetrators. One side of the problem was that the number of child soldiers was extremely high. ${ }^{63}$ On the other hand, their case was different than that of adults as they were manipulated and forced to commit crimes in most of the cases. Accordingly, the Special Court has no jurisdiction over any person who was under the age of 15 years at the time of the commission of the crime. ${ }^{64}$

Special rules apply for perpetrators between the ages of 15 and 18 years at the relevant date. In their cases the Court has the power to prosecute, but has to take into account the main aim of their reintegration into their communities. In their cases special measures can be ordered by the Court, such as community service orders, counseling, correctional, educational and vocational training programs or approved schools. ${ }^{65}$ These provisions indicate a useful

\footnotetext{
58 William A. Schabas, The Sierra Leone Truth and Reconciliation Commission, in RoADS TO RECONCILIATION, 129, 134 (Lexington Books, 2005)

59 S.C. Res. 1315, 14 August 2000, U. N. Doc. S/RES/1315 (2000) Art. 3

60 Statute of the Special Court for Sierra Leone. (note 50), Art. 1 (1)

$61 \quad$ MCDONALD (note 49), 957

62 Statute of the Special Court for Sierra Leone. (note 50), Art. 1 (2)

63 More than 10,000 children were recruited during the civil war.

64 Statute of the Special Court for Sierra Leone. (note 50), Art. 7 (1)

65 Statute of the Special Court for Sierra Leone. (note 50), Art. 7 (2)
} 
contribution of the Court to reconciliation. Moreover, the Statute recommends the reconciliation mechanism in cases where it seems to be more appropriate to address the case of the affected juvenile offender. ${ }^{66}$

These provisions were also inevitable because the system of juvenile justice does not work sufficiently well in Sierra Leone. The age limit for criminal responsibility in Sierra Leone is 10 years under domestic law, which is too low by international standards. The Children and Young Persons Act of Sierra Leone does not prohibit the imposition of life imprisonment on a juvenile, and the domestic courts often use this punishment for young offenders. The other weak point of the system is that persons between the ages of 14 and 17 years can be sent to adult prisons. Detained juveniles who are awaiting trial are not always tried as quickly as they should be. Because of this delay, they must spend much more time detained than would be legally acceptable. The magistrates working at juvenile courts do not receive special training on children's rights and issues of juvenile justice. Beyond this lack of special knowledge that would be required to ensure fair trial guarantees, in most cases juveniles are not represented in court and do not receive legal advice when they are arrested and during their detention in police cells. ${ }^{67}$

It is obvious that the functioning of authorities for juvenile justice seriously violates the international standards included in the Convention of the Rights of Child and the UN Standard Minimum Rules for the Administration of Juvenile Justice. The latter document includes general and also more specific rules, and in both categories there are norms violated by the justice system in Sierra Leone. According to the "Beijing Rules" young people "require particular care and assistance with regard to physical, mental and social development". In order to reach this aim, professional training and refresher courses shall be ensured for all the personnel dealing with juvenile cases. ${ }^{68}$ The Beijing Rules encourage states to avoid criminal proceeding and prefer alternative solutions if possible. ${ }^{69}$ The Commentary of this article emphasizes that in many cases non-intervention is the best solution, and recommend redirection of young offenders to community support services instead of a criminal process in order to avoid the negative effects of such proceedings (for instance the stigma of conviction and sentence).

In these cases the truth and reconciliation process can be an optimal solution, which can be a forum for former child-soldiers to clarify before their community what crimes they committed and why they committed them, so that they can get a chance to return to society. This was obvious to the drafters of the Act on the establishment of the Commission therefore, the relevant provision of the document declared that the Truth and Reconciliation Commission during its functioning must give special attention to the experiences of children within the armed conflict. ${ }^{70}$ During its work, which was closed in 2004, the Commission fulfilled this obligation: one of its key themes was the issue of children affected by war. It followed the Recommendations made by the expert group meeting in June $2001,{ }^{71}$ and treated child perpetrators primarily as victims and gave special attention to girls and gender-based violence. In the case of children it preferred the confidentiality of hearings and ensured the assistance of psychosocial workers and the presence of parents. Its personnel also counted with experts on issues affecting children. The proceedings included traditional ceremonies

\footnotetext{
$66 \quad I d$, Art. $15(5)$

67 Rachel Harvey, Juvenile Justice in Sierra Leone. An Analysis of Legislation and Practice. (The Children and Armed Conflict Unit, 2000) available at: www.essex.ac.uk/armedcon/story id/000013.htm 68 United Nations Standard Minimum Rules for the Administration of Juvenile Justice. ,The Beijing Rules” November 29, 1985 A/RES/40/33 Art. 22

$69 \quad$ Id, Art. 11

70 The Truth and Reconciliation Act. (note 55), Art. 6 (2)(b)

71 InTERNATIONAL CRIMINAL JUSTICE AND CHILDREN. 132 (No Peace Without Justice - UNICEF Innocenti Research Centre, 2002)
} 
acting as a symbolic gesture that the child is accepted back into the community. For example, in Northern Sierra Leone inhabitants of the affected village washed the soles of children and then their mothers drank the water used for it. ${ }^{72}$ At the end of its functioning the Commission published a child version of its Final Report as well, that had been written with the assistance of children in order to facilitate a better understanding of the Report. ${ }^{73}$

Beyond child perpetrators, the narrow scope of personal jurisdiction of the Special Court logically resulted in the fact that the investigations of the Commission covered a much broader spectrum of cases and affected persons. The same statement is valid related to internal judicial bodies, as beside individuals the fact-finding activity of the Truth and Reconciliation Commission affected different social groups, political and economic actors (for instance those with interests in the diamond business) and foreign actors as well. This broad determination of personal jurisdiction was essential for the Commission to be able to draw an overall picture of past abuses.

\section{Paragraph 3. Lack of proper regulation of cooperation}

A further important question appeared with the simultaneous functioning of the two institutions, namely, how to regulate their relation. In this respect, the example of Sierra Leone cannot be avoided. The OHCHR organized a workshop with the support of the UNAMSIL in order to discuss the possible rules applicable to the relation of the two institutions. There were two dominant views: supporters of the one stated that criminal proceedings would affect consolidation in a negative way, so a strong truth commission should be established that would be independent of the Special Court. According to the other view, a reconciliation process with the declaration of amnesty would not be consistent with the obligation of the state to call to account the perpetrators. Therefore, the Commission should play only a subsidiary role beside the Court and it must support the functioning of the judicial body by unconditional information-sharing. These debates were closed without any specific result, but it was decided that draft guidelines applicable to the relation of the Court and the Commission needed to be determined. Later on, the OHCHR and the UN Office for Legal Affairs organized a meeting of experts where the following general principles were adopted: the aims of the functioning of the two institutions are different and both aims shall be achieved in order to establish long-term consolidation, so complementarity is needed; accordingly, the priority of the Special Court against domestic courts does not exist related to the Commission; and the cooperation shall be grounded by an agreement including detailed regulation of their relation. ${ }^{74}$

A stronger connection of the two institutions could not have been possible due to several reasons. For instance, the Court would not have been able to use the statements given to the Commission as evidence, since the proper degree of reliability could not have been guaranteed during the proceedings before the Commission. In the meantime, an automatic information-sharing system would have deterred former perpetrators from participating in the reconciliation process. Parallel functioning on the basis of complementarity, more intensive

\footnotetext{
$72 \quad I d, 135$

Overview of the Sierra Leone Truth and Reconciliation Commission Report. available at: www.nuigalway.ie/human_rights/Docs/Publications/Sierra\%20Leone\%20Report/SL.TRC.Overview.pdf William A. Schabas, A syergistic relationship: the Sierra Leone Truth and Reconciliation Commission and the Special Court for Sierra Leone, 15 (1-2) CRIMINAL LAW FORUM 24, 26-27 (2004)
} 
cooperation related to witness-protection, conditional information-sharing and common action in order to raise public awareness would have increased the efficiency of both institutions.

Unfortunately the agreement proposed by the expert meeting was never adopted and the principle of complementarity was not enforced in practice. Although the Act on the establishment of the Commission declared its total independence and pursuant to the relevant provisions the priority of the Court applies only to national judicial bodies, despite the theoretical independence of the two institutions different views seemed to be born among the walls of the Court and those of the Commission. Predictably, the Court argued for its own priority in certain practical situations and the Commission declared its opinion on the necessity of independent simultaneous functioning. According to the arguments of the Department of Justice of Sierra Leone ${ }^{75}$ legal grounds for the priority of the Special Court could be found in the agreement concluded by the United Nations and the government of Sierra Leone, which says that the government shall support the functioning of the Court in the identification of affected persons, information-sharing, arrest and in any other field where it is needed. ${ }^{76}$ At the same time it cannot be forgotten that the Commission was not an organ of the government, so this obligation did not apply to it. Beyond the international treaty mentioned earlier, the 2002 Special Court Agreement (Ratification) Act referred to the obligation of all actors of the country to cooperate. Accordingly, all individuals or legal entities and any other institutions established according to the law of Sierra Leone shall comply with the orders adopted by the Special Court. ${ }^{77}$

The Court followed its view on priority in practice, as was obvious in the case of request that arrived from the Commission in which it asked the Court to give out accused persons detained by it in order to involve them in a hearing. Among others, this affected Sam Hinga Norman, who was a deputy minister of defense and the chief of the Civil Defense Forces and was still a member of the government in 2003, when he was arrested in his own office. Many saw him as a national hero leading fights against the Revolutionary United Front, forgetting all the atrocities committed by the CDF, such as forced cannibalism. Earlier, in February 2003 he participated in the opening ceremony of the Commission where he even made a promise to meet a commissioner later in order to make an interview. In the summer of the same year, the legal representative of Norman refused the interview when the Commission requested it officially. After the Commission had closed the functional period of hearings, Norman changed his mind and stated that because of the prolongation of the Court proceedings he expected judgment from the people of Sierra Leone, and therefore he would have liked to participate in a public hearing. This change in Norman's behavior was obviously aimed at the manipulation of the criminal proceedings by the pressure of public opinion. Therefore, the question came again into focus: may the Commission hear defendants of the Special Court before the closure of their proceedings?

The draft of a guideline prepared by the Registrar of the Court would have empowered the judicial body to decide on this question. It would have entitled the judges to decide whether the Commission hearing could occur and what questions could be posed at the hearing. Moreover, the interview would have been supervised by a lawyer from the Court who could have interrupted or even suspended the hearing. Due to the strong negative reaction of the Commission the draft was modified so that the application for a hearing could be rejected only by the presiding judge of the Court if he thought that it would not serve the interest of justice. The Commission was far from satisfied with the second version, either. At the same time it submitted an application to the Court relating to a hearing of Norman. The

\footnotetext{
$75 \quad I d, 36$

76 Agreement between the United Nations and the Government of Sierra Leone. (note 27), Art. 17

77 Special Court Agreement (Ratification) Act, April 25, 2002. available at: www.sc-

sl.org/documents.html, Art. 21. (2)
} 
application was rejected by Justice Thompson with the argument that the application mentioned Norman as a central figure of the conflict, which statement could be understood as a kind of pre-judgment, violating the principle of the presumption of innocence. This was interesting because a part of the indictment including similar sentences had been earlier confirmed by the Court. The real aim and reason was to hinder the possible influence on the adjudication of the Court which was emphasized by Justice Robertson in his decision about the appeal as well. He emphasized that a public hearing may seem to be a trial which could create expectations in the public regarding a future judgment of the Court. ${ }^{78}$

The view of priority defended by the measures taken by the Court can be rebutted by a teleological interpretation. Considering the main aim of the establishment of the Court it is clear that the main intent was to strengthen the entire system of transitional justice, and not to undermine the functioning of one of its main institutions such as the Commission. This is mirrored by Security Council Resolution 1315 on the establishment of the Court, which declares that the aim of its functioning shall be to strengthen a reliable and credible justice system, to call to account persons responsible for the most serious crimes in a proper way and to facilitate reconciliation. ${ }^{79}$ Accordingly, a cooperative relation should have been built between the Court and the Commission in order to serve together the common aim of national unity and consolidation. This approach appeared in the statement of Joseph Humper, the President of the Truth and Reconciliation Commission, in which he said that both institutions were "going to the promised land, but by different roads." 80

Beyond the debates referred to, the fact, that the two institutions were working separately, led to the duplication of work and the waste of time and financial resources. As a result of having failed to inform the population in a proper way, very often even local people were not aware of the functioning of the two institutions. This can be well-illustrated by a small story about a citizen who asked a taxi driver in Freetown to take him to the Special Court who was finally driven to the building of the Commission. ${ }^{81}$

\section{Paragraph 4. Rules adopted related to information-sharing without practical enforcement}

One of the most significant questions related to the possible cooperation was the regulation of information-sharing and at the end this remained the only field in which the debates could be settled. The affected non-governmental organizations suggested different solutions. The International Center for Transitional Justice held that certain conditions should be determined regarding information-sharing; Amnesty International preferred free information flow. ${ }^{82}$ Finally, the government gave a narrow discretionary power to the Court to ask information from the Commission. In this case three conditions needed to be fulfilled: the information requested had to be specific, essential to a fair determination of the innocence of

\footnotetext{
$78 \quad$ SCHABAS (note 74), 44-49

79 UN Security Council Resolution 1315 (2000)

80 SCHABAS (note 58), 144

81 Abdul Tejan-Cole, The Complementary and Conflicting Relationship between the Special Court for Sierra Leone and the Truth and Reconciliation Commission, 5 YEARBOOK OF INTERNATIONAL HUMANITARIAN LAW 313, 323 (2005)

$82 \quad$ Elizabeth M. Evenson, Truth and Justice in Sierra Leone: Coordination between Commission and Court, 104 COLUMBIA LAW REVIEW 730, 765 (2004)
} 
the accused, and could not reasonably be obtained from any other source. ${ }^{83}$ The problem was that it was not clarified who was entitled to determine whether these conditions were met.

This regulation followed the so-called "conditional information sharing model", but according to the reports of a local non-governmental organization, PRIDE, the lack of specific determination of conditions caused in practice the free exchange of information, mainly in the direction of the Special Court. ${ }^{84}$ This was a significant obstacle to the participation of excombatants in the reconciliation process. Many of them were afraid that statements given to the Commission would be used against them, or that after these statements they would be summoned by the Special Court as a witness in the proceedings of their commanders, upon whom they were still dependent.

This view was not supported by the statements of Prosecutor David Crane who said at the beginning of the functioning of the Court that he did not intend to use any materials deriving from the Commission and he wanted to rely only on information obtained by the Court. ${ }^{85}$ At the same time, obviously due to the nature of the functioning of the Commission, some information could be obtained by the Court as a result of public hearings. It was also vital to handle the information on a confidential basis in cases where the personal safety of the affected person depended on that, especially because it was the only tool in the hand of the Commission for witness protection. Article 7 (3) of the Truth and Reconciliation Commission Act entitled every person to give a statement on a confidential basis, and gave no one the right to oblige the Commission to give out the information included in these statements. ${ }^{86}$ Accordingly, the Commission did not give out any such information after the closure of its work and publication of its Final Report, and despite the debates on this issue, it insisted on this opinion and suggested also in the Report that these statements must continue to be protected. ${ }^{87}$

Regarding the same issue, the procedural rules applicable to the Special Court refer to confidentiality within the context of the relation between the legal representative and his client. ${ }^{88}$ Furthermore, Article 17 (4) g) of the Statute declares the right of the defendant that he cannot be obliged to confess to being guilty. ${ }^{89}$ The rules applicable to the ad hoc tribunals (ICTY, ICTR) to be followed by the Special Court broaden the scope of this right and apply it to witnesses as well. According to the (minority) opinion of William Schabas these rules should also be applied to the witnesses appearing before the Commission on the basis of the logic of the system. ${ }^{90}$ This argument can be debated, as a statement given at the Commission cannot result in automatic criminal procedures. At the same time, considering the possible practical consequence that the statement may be obtained by the Court, this opinion may be reasonable. It raises a further question as to whether there is any deterrent against the appearance of ex-combatants before the Commission deriving from this uncertainty.

This was a paramount issue, since the participation of ex-combatants was of outstanding importance. It was essential in order to reintegrate the more than 50,000 people having taken part in the hostilities into their former communities. ${ }^{91}$ On the other hand, how could the

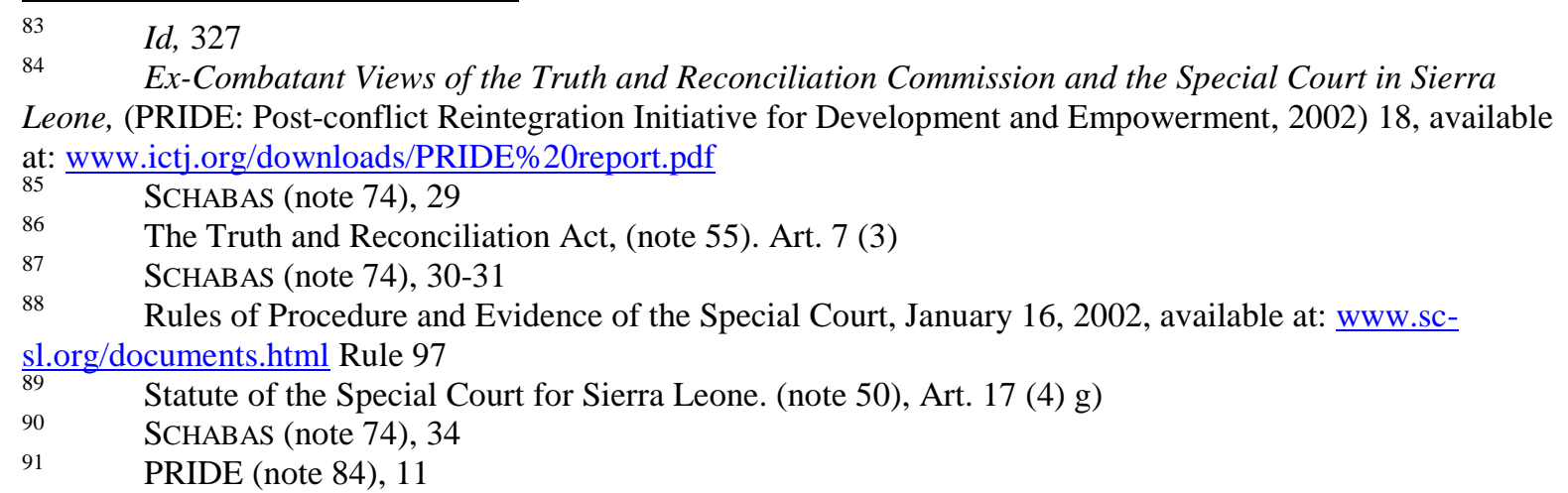


victims be reconciled with perpetrators who were not present at the proceedings? Without reconciliation and reintegration one alternative remained for ex-combatants: the way back in war. It cannot be forgotten that ex-combatants had vital information about the details and nature of the conflict, and this information was fundamentally necessary for creating a clear and whole picture of past events.

While local organizations felt that ex-combatants were deterred from appearing before the Commission because they were not sure of the separate functioning of the two institutions, there are experts who do not think that this was a significant problem. They believed that this issue was determined by emotional reactions rather than by rules on amnesty or informationsharing, because very soon it became clear for combatants that the Special Court was hunting "big fish", and that foot-soldiers did not fall under its authority. ${ }^{92}$

Nevertheless it can be stated without a doubt that in general greater public awareness facilitates the increase of the number of participants in the reconciliation process, since former perpetrators and victims are fully aware of the consequences of their statements given to the Commission.

\section{SECTION 5. TRUTH COMMISSION AS AN INTEGRATED PART OF THE CRIMINAL JUSTICE SYSTEM: EAST TIMOR}

As is illustrated by the cases elaborated above, the first truth commissions were nonjudicial bodies. This situation changed with the establishment of the South African commission which was empowered to decide about individual amnesty pleas. This tendency was continued by the commission of East Timor. Moreover, this commission became an integrated part of the criminal justice system.

The territory of the country was invaded by Indonesian troops in 1976 after a two yearlong civil war that lead to the end of the Portuguese administration. After 23 years of Indonesian occupation (which was never recognized by the international community) the United Nations intervened in the situation establishing the UN Mission in East Timor (UNAMET) in 1999. In a referendum on August 30 the same year 78.5 percent of the appearing citizens (98 percent of the eligible voters appeared) declared their will to refuse any proposals for autonomy and to gain independence. At the same time it was obvious that Indonesia would not give freedom at such a low price. Irregular armed groups were organized by some generals of the Indonesian army composed of supporters of the integration in order to prevent losing the colony. The targets of their attacks were those who supported independence. During a period of several weeks more than 1,500 people were killed, approximately 500,000 civilians were chased out of their homes and 250,000 were deported to West Timor, while 73 percent of the houses and buildings were destroyed. Finally, violent acts by East Timorese and the pressure of the UN compelled the Indonesian armed forces to leave the territory, and on September 28, 1999 an agreement was concluded between Portugal, Indonesia and the UN giving the authority of administration to the United Nations. In October the UN Security Council established the United Nations Transitional Administration in East Timor (UNTAET) by Resolution 1272 (1999). The mission was

92 Some of these authors: SCHABAS (note 74), 30., EVENSON (note 82), 762., Priscilla Hayner, THE SIERRA LEONE TRUTH AND RECONCILIATION COMMISSION: REVIEWING ITS FIRST YEAR, 4 (International Center for Transitional Justice, 2004) 
comprised of three main components: governance and public administration; humanitarian assistance and emergency rehabilitation; and a military component.

As part of the development project of the justice system, the Office of the General Prosecutor, the Service of Legal Representation, three district courts, an Appeal Court and several prisons in the capital of Dili were established in the year 2000. Two international experts and the expert delegation of the International Development Law Institute arrived in Dili in order to give some expert support in the training of judges. A part of this process was the establishment of those judicial panels that received exclusive jurisdiction regarding the most serious crimes ${ }^{93}$, namely, the Special Panels for Serious Crimes that comprised the Serious Crimes Unit in the Dili District Court. ${ }^{94}$

\section{Paragraph 1. The establishment and functioning of the Commission for Reception, Truth and Reconciliation}

Alongside the need for proper repression of serious crimes the necessity for revealing of truth about past events and solving problems raised by the high number of lower level perpetrators through an alternative justice system grew more and more urgent. A solution was given by the 2001/10 UNTAET Resolution establishing the Commission for Reception, Truth and Reconciliation (CAVR - the Portuguese acronym) in April 2002. The Commission had a mandate for two years that was prolonged with six more months. Its main functions became (i) to investigate the nature and causes of human rights abuses committed between 1974 and 1999; (ii) to serve the interest of victims and promote reconciliation; (iii) to support the perpetrators in returning to their communities; (iv) to write reports on its findings and to make recommendations for future measures that should be taken for the above aims, and (v) to refer the cases of the most serious crimes to the Office of the General Prosecutor (OGP). The Resolution empowered the Commission to adopt its own rules of procedure and to establish its organs if necessary for the fulfillment of its functions. ${ }^{95}$

In order to carry out its investigations the CAVR had the authority to convene hearings, to issue subpoenas, to request information from relevant authorities or individuals in East Timor, to be present at exhumations relevant to Commission inquiries, and to request an Investigating Judge of the District Court to issue a search warrant to enable police authorities to search premises considered as containing evidence relevant to a Commission inquiry. Where the CAVR was convinced that it would be in the interests of justice, or there was a likelihood that harm would ensue to any person as a result of the proceedings being open, it could order that such proceedings be held behind closed doors. ${ }^{96}$

During its work the Commission heard more than 1400 cases. For the initiation of proceedings the perpetrator had to submit an application that included a detailed description of the relevant events and acts, an acknowledgement of the commission of crimes, an explanation of the connection between those acts and the conflict and the identification of the addressed local community.

\footnotetext{
93 Rule of Law: Judiciary, in EAST TIMOR UPDATE, available at: www.un.org/peace/etimor/untaetPU/ETupdateMGE.pdf (2000) Unfulfilled Expectations: Community Views on CAVR's Community Reconciliation Process, in JUDICIAL SYSTEM MONITORING PROGRAM 9 (2004)

95 UNTAET Regulation 2001/10 on the Establishment of a Commission for Reception, Truth and Reconciliation in East Timor (July 13, 2001) Art. 3

Id, Art. 14-16
} 
The hearing ensured the possibility for the perpetrators, victims and the affected members of the community to express their views about the negotiated events. The process was closed with the issuance of a Community Reconciliation Agreement that included the description of the revealed facts, the acknowledgement of the commission of crimes and the service that the perpetrator had to provide for the community. ${ }^{97}$ This Agreement ensured criminal and civil legal impunity to the relevant individual concerning the act mentioned in the Agreement, but any failure of the fulfillment of the obligations imposed by the Agreement was qualified as a criminal act. ${ }^{98}$ The courts enjoyed only a limited authority to control this decision-making process. They could examine whether the sanction imposed by the Commission - these included community service, reparation, public apology or another act of contrition $^{99}$ - exceeded what was reasonably proportionate to the acts disclosed, and whether the act was a violation of human rights principles. ${ }^{100}$ In the majority of cases former perpetrators were required to make an apology to the community rather than to carry out any specific act of community service or to provide compensation to the victim. ${ }^{101}$

\section{Paragraph 2. Factors encouraging perpetrators to participate and information- sharing}

Strong motivation for former perpetrators to participate in the reconciliation processes plays an outstanding role in the long-term reestablishment of the integrity of local communities. One of the reasons for this is that without broad participation the reconciliation process cannot be completed. Just to mention one example, an East Timorese suspect appeared before the Commission in order to clean his name before the community, to prove that he was only an eye-witness to murders. He identified the two actual perpetrators, but those two persons did not return to East Timor, and accordingly did not appear before the CAVR. As a result, although the affected person was reaccepted into his community, the widows of the victims never talked to him as they still suspected him of the commission of the murder. ${ }^{102}$ The same effect occurs with those members of the community who do not participate in the hearings and then question the credibility of the process.

Accordingly, great emphasis should be put on promoting all those circumstances that might encourage the affected individuals to appear before the commission, and also on reducing those factors that might discourage them. In the case of East Timor the commission was entitled to accept information on a confidential basis, but it could not guarantee anything in regard to a possible criminal investigation. Even this information had to be disclosed to the Office of the General Prosecutor if requested. In such cases it becomes more likely that the proper functioning of the truth commission cannot be realized because of the witnesses' fear of prosecution. The other side of the coin is that protection or privilege over information given to the commission might protect perpetrators who should be brought to trial. This may

\footnotetext{
$97 \quad$ Id, Art. $23-27$

$98 \quad$ Id, Art. $28-30$

$99 \quad$ Id, Art. 27.7

100 Carsten Stahn, Accomodating Individual Criminal Responsibility and National Reconciliation: the UN

Truth Commission for East Timor, in 95 THE AMERICAN JOURNAL OF INTERNATIONAL LAW 952, 959 (2001)

$101 \quad$ UNFULFILLED EXPECTATIONS (note 94), 32

$102 \quad I d, 14$
} 
limit the information available to the prosecution and the defence, and might result in impunity. ${ }^{103}$

This latter argument was the basis of the regulation on the right of the OGP to request information from the Commission. ${ }^{104}$ Generally speaking, a relatively good relationship was developed between the SCU and the CAVR in terms of cooperation.

Regarding the question of which institution had authority over a specific case, the SCU had a stronger position. A copy of all statements received by the Statements Committee of the Commission had to be transmitted to the OGP, which had to decide within fourteen days whether it intended to exercise its exclusive authority over serious crimes. The Commission could proceed only if the OGP refrained from exercising its special power. Nevertheless, if a hearing at the Commission revealed credible evidence about the commission of a serious crime, it had to refer the evidence to the OGP, which could then initiate an investigation. ${ }^{105}$

According to the initial regulation the Commission was not entitled to proceed in cases of serious crimes "under any circumstances", but the practical problem of the broad involvement of the population in the hostilities made it impossible to draw such a sharp line. Therefore, this wording was amended to "in principle" by the UNTAET Directive on Serious Crimes No. 2002/9. This ensured a broader scope for the Prosecutor to decide not to investigate, even over matters that could technically constitute serious crimes. ${ }^{106}$

Considering this issue another question can be raised: how can the notion of serious crimes be determined? In the East Timorese case this notion included genocide, war crimes, crimes against humanity, murder, sexual offences and torture. However, the type of crime was not the only relevant factor determining whether the Commission had authority over a certain case. According to the UNTAET Regulation on the establishment of the Commission, the question of whether it could proceed had to be determined by the following relevant factors: (i) the nature of the crime, (ii) the total number of acts committed by the affected person, (iii) whether he or she organized, planned, or ordered the crime or was following the order of someone else, and (iv) whether a serious criminal offence had been committed, in which case the SCU had exclusive authority. ${ }^{107}$ This determination had common points with the qualification of cases before gacaca courts in Rwanda regarding the leadership-factor, but here a more sophisticated regulation was given. On the other hand it did not include the age factor, although greater emphasis should have been put on this issue because of the children who were usually forced or compelled to join the armed groups.

\section{Paragraph 3. Big fish swim away}

Lack of efficiency of transitional justice institutions was reflected not only in the fact that the number of lower level perpetrators who participated in the CAVR hearings was not satisfactory. This lack was also demonstrated regarding those individuals who had held leading positions during the conflict. „Small fish” seemed to be affected at a much higher rate than their ,big" fellows. In order to avoid accountability the majority of the former leaders of

\footnotetext{
103 Patrick Burgess, Justice and Reconciliation in East Timor, in TRUTH COMMISSIONS AND COURTS: THE TENSION BETWEen CRIMINAl Justice AND the SEARCh FOR TRUTH 135, 145 (Kluwer Academic Publishers, 2004)

104 It must also be mentioned that although the OGP was entitled to request information, the same right was not granted to the defence.

105 UNTAET REGULATION 2001/10 (note 95), Art. 24 (6), 27 (5-6)

106 BURGESS (note 103), 154

107 UNTAET REGULATION 2001/10 (note 95), Schedule 1
} 
militias did not return from West Timor. Revealing of the circumstances and the accountability of perpetrators were not sufficient, which resulted in great dissatisfaction among the people of East Timor. In order to achieve these aims the efficient cooperation of the CAVR, the SCU and the government would have been necessary.

Moreover, it became a legal reality that despite the desire of people for accountability, there is no chance for the accomplishment of criminal proceedings in these high-profile cases. This is undermined by a political agreement based on the ever more intensive dialogue between the Indonesian and East Timorese governments. In the framework of this more peaceful relationship, Xanana Gusmao, President of East Timor, and Susilo Bambang Yudhoyono, President of Indonesia concluded an agreement establishing the Commission of Truth and Friendship on March 9, 2005.

The actual aim of this commission is to prevent prosecution in cases of high ranking military officers who are responsible for the commission of crimes against humanity before or during 1999. The Agreement hindered all judicial investigations into crimes committed during the Indonesian occupation. ${ }^{108}$ The fundamental necessity mentioned earlier, that the continuation of suspended investigations is essential for real reconciliation, was not taken into consideration by those who prepared the draft Agreement. The decision-making political leaders did not disguise the actual goal of this regulation either. The Prime Minister of East Timor, Mari Alkatiri, declared himself that the main aim of the establishment of the Commission was not to provide justice. ${ }^{109}$ However, the problem is that the criminal accountability of the affected perpetrators responsible for the most serious crimes is unavoidable for long-term reconciliation.

\section{Section 6. Relations With the InTERnational Criminal Court}

Chasing „big fish” will always be a paramount - and at the same time, a delicate - issue in post-conflictive societies and in this regard the International Criminal Court will play a central role in the international scene. This new institution of international criminal justice cannot be ignored in the examination of the relationship between truth commissions and criminal courts.

In the preparatory discussions at the Rome Conference there were proposals for a possible provision on truth commissions related to Article $17^{110}$, but in the end no explicit

108

„Commission of Truth and Friendship” Seeks to End the Search for Justice whilst „Commission of

Experts" Keeps it Alive. (Judicial System Monitoring Programme Press Release, 2005) available at

www.jsmp.minihub.org/Press\%20Release/CTF\&CoF/ComparingCTFandCoE(e).pdf

John M. Miller, Truth Known, East Timorese Need Justice. Accountability for Rights Crimes Remains

an International Responsibility. (2005) available at www.etan.org/news/2005/03just.htm

110 Text of Article 17:

„1. Having regard to paragraph 10 of the Preamble and article 1, the Court shall determine that a case is inadmissible where:

(a) The case is being investigated or prosecuted by a State which has jurisdiction over it, unless the State is unwilling or unable genuinely to carry out the investigation or prosecution;

(b) The case has been investigated by a State which has jurisdiction over it and the State has decided not to prosecute the person concerned, unless the decision resulted from the unwillingness or inability of the State genuinely to prosecute;

(c) The person concerned has already been tried for conduct which is the subject of the complaint, and a trial by the Court is not permitted under article 20, paragraph 3;

(d) The case is not of sufficient gravity to justify further action by the Court. 
provision on amnesties or truth commissions was included in the text of the Rome Statute, leaving in this way a broad scope for the Court to decide about this question on a case-by-case basis. ${ }^{111}$ The question of whether domestic criminal courts are functioning properly way so that it can be the basis of inadmissibility might raise several dilemmas, but in the case of a truth commission process going on in the affected country this issue may be even more challenging and a decision in favour of truth commissions would demand a very flexible interpretation of the Statute. Article 17 (a) and (b) require an investigation but they do not order that it must be a criminal one. Accordingly, the Prosecutor might find that conditional amnesty with a truth process satisfies the requirements of an investigation and decide that the case is inadmissible. ${ }^{12}$ Nevertheless, the Pre-Trial Chamber has the right to review such a decision and send a request to the Prosecutor to reconsider the decision.

It must also be mentioned that this provision has to be interpreted in a narrow way since it was drafted in a negative manner. The exceptions to the principle of admissibility are regulated as a first step, and as a second step certain exceptions are determined even for these exceptional cases. It is obvious that as far as a truth commission is concerned, the main rule would be admissibility, and the fulfilment of the conditions for inadmissibility would create an exception. ${ }^{113}$

The conditions for inadmissibility are determined in a strict sense. Under Article 17 paragraph 1(b) a case has to be investigated by the affected State and it is also required that the State has to decide not to prosecute, but not with the aim of supporting impunity, since the decision cannot result from the unwillingness or inability of the State genuinely to prosecute. With a flexible approach an alternative forum of justice, which has the power to send the case to criminal courts after the completion of its procedure might be accepted as a proper way to fulfil the conditions provided by Article 17, provided that these proceedings guarantee the basic fair trial guarantees. However, this latter requirement causes further dilemmas, as it is far from obvious whether truth commissions can ensure due process guarantees.

Theoretically, truth commissions can fulfil the criteria as their main objective is to promote reconciliation and not to support impunity. ${ }^{114}$ Effective inquiry of the facts through

2. In order to determine unwillingness in a particular case, the Court shall consider, having regard to the principles of due process recognized by international law, whether one or more of the following exist, as applicable:

(a) The proceedings were or are being undertaken or the national decision was made for the purpose of shielding the person concerned from criminal responsibility for crimes within the jurisdiction of the Court referred to in article 5;

(b) There has been an unjustified delay in the proceedings which in the circumstances is inconsistent with an intent to bring the person concerned to justice;

(c) The proceedings were not or are not being conducted independently or impartially, and they were or are being conducted in a manner which, in the circumstances, is inconsistent with an intent to bring the person concerned to justice.

3. In order to determine inability in a particular case, the Court shall consider whether, due to a total or substantial collapse or unavailability of its national judicial system, the State is unable to obtain the accused or the necessary evidence and testimony or otherwise unable to carry out its proceedings."

111 Darryl Robinson, Serving the Interests of Justice: Amnesties, Truth Commissions and the International

Criminal Court, in BRINGING POWER TO JustiCE?: THE PROSPECTS OF THE INTERNATIONAL CRIMINAL COURT

483 (McGill-Queen's University Press, 2006)

112 Carsten Stahn, Complementarity, Amnesties and Alternative Forms of Justice: Some Interpretive Guidelines for the International Criminal Court, in 3 JOURNAL OF INTERNATIONAL CRIMINAL JUSTICE 695, 697 (2005)

$113 \quad$ Id, 709

Exception to admissibility: “the Court shall determine that a case is inadmissible where:...” (Art. 17 para. 1)

Exception to the exceptions: "unless the State is unwilling or unable genuinely to carry out the investigation or prosecution;" (Art. 17 para. 1a)

114 STAHN (note 112), 715 
testimony or written evidence with public identification of the perpetrator can be accomplished by a properly functioning truth commission, and its independence and impartiality might be safeguarded, especially with international support, but it is still far from probable that a truth commission process could ever be enough for the Prosecutor and the PreTrial Chamber to decide in favor of that process on the basis of inadmissibility.

There is a slight possibility that the UN Security Council would initiate the deferral of the investigation or prosecution preferring a truth process as a more optimal solution according to Article $16^{115}$ of the Statute, and adopting a resolution under Chapter VII of the UN Charter. This is not likely to be applicable to truth processes, since this decision is valid only for a temporary period of 12 months and it may not serve as an instrument to ensure permanent respect for an amnesty law and a reconciliation process. ${ }^{116}$ However, as it is a renewable request and considering the strong opposition of the United States related to the functioning of the Court, it is quite possible that the Security Council will make such a decision in the future, ensuring priority to an internal solution of transitional justice instead of criminal jurisdiction at the international level.

However, a decision about the preference of a truth commission process is still the most probable under the conditions set out in Article $53^{117}$ of the Rome Statute. This entitles the Prosecutor to decide not to investigate if it would not be in the interest of justice, and the PreTrial Chamber of the Court does not have any objection regarding this decision. In this context the notion of justice is comprehended in a broad way, it is understood as a public interest. For instance, if trials contributed directly to the prolongation of political instability or to the renewal of violence, they could hardly be interpreted as being in the interest of justice. ${ }^{118}$ On the other hand, the existence of a truth commission in the affected country makes the decision about the suspension of investigation more probable if the Prosecutor sees another mechanism in the country serving transitional justice.

There are numerous circumstances that must be considered by the Prosecutor before taking such a decision, namely: (i) Was the establishment of the institution based on a democratic will? (ii) Can the preference of a truth commission process over criminal proceedings be explained by real economic, social and political necessities? (iii) Can a full and effective inquiry of facts be accomplished by the commission? (iv) Are the perpetrators identified publicly? (v) Is the commission independent and proper to ensure due process

$115 \quad$ Text of Article 16:

„No investigation or prosecution may be commenced or proceeded with under this Statute for a period of 12 months after the Security Council, in a resolution adopted under Chapter VII of the Charter of the United Nations, has requested the Court to that effect; that request may be renewed by the Council under the same conditions.”

116 STAHN (note 111), 699

$117 \quad$ Text of the relevant passages of Article 53:

"1. The Prosecutor shall, having evaluated the information made available to him or her, initiate an investigation unless he or she determines that there is no reasonable basis to proceed under this Statute. In deciding whether to initiate an investigation, the Prosecutor shall consider whether: [...]

(c) Taking into account the gravity of the crime and the interests of victims, there are nonetheless substantial reasons to believe that an investigation would not serve the interests of justice."

2 If, upon investigation, the Prosecutor concludes that there is not a sufficient basis for a prosecution because: $[\ldots]$

(c) A prosecution is not in the interest of justice, taking into account all the circumstances, including the gravity of the crime, the interests of victims and the age or infirmity of the alleged perpetrator, and his or her role in the alleged crime; $[. .$.

3 (b) In addition, the Pre-Trial Chamber may, on its own initiative, review a decision of the Prosecutor not to proceed if it is based solely on paragraph 1 (c) or 2 (c). In such a case, the decision of the Prosecutor shall be effective only if confirmed by the Pre-Trial Chamber."

$118 \quad$ SEILS and WIERDA (note 10), 12 
guarantees? (vi) Is there any kind of penalty such as social service imposed on the perpetrators? (vii) Does it serve the interests of victims and the aim of justice? ${ }^{119}$

The notion of the 'interest of victims' is not easy to determine it depends on the specific circumstances of the situation. In some cases criminal justice would rather serve their interests than a reconciliation process and reintegration of perpetrators with a conditional amnesty. The latter version could be the basis of the South African reconciliation process, but the people of Rwanda could not be expected to accept such a solution. Likewise, the 'interest of justice' is linked to specific cases and not to general criteria. Regarding this issue it is important to devote attention to the possibility that there might be an urgent need for the establishment of both criminal courts and truth and reconciliation commissions, and in these cases their proper and efficient parallel functioning must be ensured through well-prepared regulations. At the same time it must be emphasized that even the simultaneous and efficient work of these two types of institutions is not enough for a long-term reconciliation. A fundamental change in the minds of people, proper reparations to the victims, economic development and democratic changes in the structure of the institutions are indispensable as well in order to reach real reconciliation. 